NBER WORKING PAPER SERIES

\title{
CAN MILITANTS USE VIOLENCE TO WIN PUBLIC SUPPORT? EVIDENCE FROM THE SECOND INTIFADA
}

\author{
David A. Jaeger \\ Esteban F. Klor \\ Sami H. Miaari \\ M. Daniele Paserman \\ Working Paper 16475 \\ http://www.nber.org/papers/w16475 \\ NATIONAL BUREAU OF ECONOMIC RESEARCH \\ 1050 Massachusetts Avenue \\ Cambridge, MA 02138 \\ October 2010
}

We are deeply grateful to the Development Studies Programme at Bir Zeit University for kindly providing us with their micro data. The authors thank seminar participants at numerous universities and conferences for helpful comments. David Jaeger and Daniele Paserman thank the Samuel Neaman Institute for financial support. Esteban Klor thanks the NBER and Boston University for their warm hospitality while he was working on this project. The views expressed herein are those of the authors and do not necessarily reflect the views of the National Bureau of Economic Research.

NBER working papers are circulated for discussion and comment purposes. They have not been peerreviewed or been subject to the review by the NBER Board of Directors that accompanies official NBER publications.

(C) 2010 by David A. Jaeger, Esteban F. Klor, Sami H. Miaari, and M. Daniele Paserman. All rights reserved. Short sections of text, not to exceed two paragraphs, may be quoted without explicit permission provided that full credit, including $(\mathrm{O}$ notice, is given to the source. 
Can Militants Use Violence to Win Public Support? Evidence from the Second Intifada

David A. Jaeger, Esteban F. Klor, Sami H. Miaari, and M. Daniele Paserman

NBER Working Paper No. 16475

October 2010

JEL No. D72,D74,H56

\begin{abstract}
$\underline{\text { ABSTRACT }}$
This paper investigates whether attacks against Israeli targets help Palestinian factions gain public support. We link individual level survey data to the full list of Israeli fatalities during the period of the Second Intifada (2000-2006), and estimate a flexible discrete choice model for faction supported. We find some support for the "outbidding" hypothesis, the notion that Palestinian factions use violence to gain prestige and influence public opinion within the community. In particular, the two leading Palestinian factions, Hamas and Fatah, gain in popularity following successful attacks against Israeli targets. Our results suggest, however, that most movement occurs within either the secular groups or the Islamist groups, and not between them. That is, Fatah's gains come at the expense of smaller secular factions while Hamas' gains come at the expense of smaller Islamic factions and the disaffected. In contrast, attacks by the Palestinian Islamic Jihad lower support for that faction.
\end{abstract}

David A. Jaeger

Graduate Center

City University of New York

365 Fifth Avenue

New York, NY 10016

and University of Cologne

djaeger@gc.cuny.edu

Esteban F. Klor

Dept. of Economics

Hebrew University

Mount Scopus

Jerusalem ISRAEL 91905

eklor@mscc.huji.ac.il
Sami H. Miaari

Department of Economics

University of Haifa

Mount Carmel

Haifa, 31905

Israel

and Ruppin Academic Center

and

smiaari@gmail.com

M. Daniele Paserman

Department of Economics

Boston University

270 Bay State Road

Boston, MA 02215

and Hebrew University

and also NBER

paserman@bu.edu 


\section{Introduction}

The Second Palestinian Intifada has been characterized not only by the intensity of violence between the Palestinians and Israel, but also by the struggle between the different Palestinian factions for supremacy within the Palestinian community. The Intifada has had profound consequences for the whole Palestinian political landscape. For example, Hamas, an Islamist movement responsible for more than 40 percent of Israeli fatalities between 2000 and 2005, secured a large victory in the 2006 elections for the Palestinian Legislative Council. ${ }^{1}$ Can Hamas's electoral success be linked causally to its violent campaign against Israeli targets? In this paper we seek to answer this question specifically, and, more broadly, we investigate the extent to which Palestinian factions can use violence to win public support from their constituents.

Mia Bloom (Bloom 2004, 2005) has hypothesized that Palestinian factions are engaged in competition for leadership within the community and use attacks against Israeli targets to increase their prestige and influence the preferences of the Palestinian population. There are a number of potential theoretical explanations for why attacks against Israelis could boost public support for the faction responsible. A first possibility is that violence against Israel can be viewed as a public good. The Palestinian public has a taste for retaliation against Israel's actions (de Figuereido and Weingast 2001), and therefore factions that are able to successfully attack

\footnotetext{
${ }^{1}$ Hamas eventually took control of the whole Gaza Strip after forcing out Fatah forces loyal to Palestinian President Mahmoud Abbas in June 2007. As a result of the 2007 violence, the territory controlled by the Palestinian Authority is today de facto divided into two entities, the Hamas-controlled Gaza Strip and a Fatah-controlled West Bank.
} 
Israeli targets gain in popularity. This model predicts that successful attacks by a given faction will raise support for that faction at the expense of all other factions.

A second closely related explanation is that successful attacks are used as a device that signals the faction's ability to deliver public goods. Successful attacks reveal that the faction is of "high quality" and will also be effective in the provision of other public goods such as schools, hospitals, and other social services. This argument is directly made by Lapan and Sandler (1993) and by Kydd and Walter (2006), and also implied in the analysis put forward by Berman and Laitin (2008) to explain the effectiveness of religious radicals in conducting violent insurgent campaigns. According to Berman and Laitin (2008), radical groups are able to conduct effective campaigns because the prohibitions they impose on their members allow them to select only those most committed to the cause and those less likely to defect. Hence, successful attacks against Israeli targets signal that the faction responsible has highly committed members, and that those members will not be tempted by corruption and will deliver good governance in other dimensions of public activity as well.

As in the "violence as public good" model, the "violence as signal" model predicts that successful attacks by a given faction will raise support for that faction at the expense of all other factions. Both of these explanations predict that violence by a given faction will raise support for that faction. This need not necessarily be the case, however. An alternative theory posits that Palestinians commit acts of violence to provoke an indiscriminate violent Israeli response. Israeli indiscriminate violence in turn, causes the overall radicalization of the Palestinian population, mostly because they dampen economic opportunities in the market economy (Bueno de Mesquita and Dickson, 2007; Blomberg et al., 2004). Therefore, only radical factions, such as Hamas and the Palestinian Islamic Jihad (PIJ), benefit from violence, whereas relatively 
moderate factions such as Fatah will lose public support in response to violence by any of the factions. $^{2}$

To answer these questions, we have assembled a unique data set that links micro-level survey data on Palestinian public opinion to the complete list of Israeli and Palestinian fatalities from the outset of the second Intifada up to the end of 2005. Moreover, we have identified for each Israeli fatality the district of origin of the attacker and his or her organizational affiliation. To study the effect of violence on Palestinian public opinion, we estimate a completely flexible discrete choice model where we allow the choice of faction supported to depend on the number of Israeli fatalities claimed by each faction in the three months preceding the survey. We control for potential endogeneity between local public support and violent activity by including a full set of district dummies in each of our regressions. Hence, the effect of interest is identified from variation within districts and over time in violence and public opinion. The model is flexible in the sense that the effect of the number of Israeli fatalities claimed by Hamas, say, on support for Hamas is not restricted to be the same as the effect of the number of Israeli fatalities claimed by Fatah on support for Fatah. Similarly, no restrictions are imposed on any of the cross-effects (i.e., the effect of violence by one faction on support for other factions).

We find some support for the outbidding hypothesis, with one notable exception. For the two main factions, Fatah and Hamas, successful attacks against Israeli targets are associated with an increase in public support, even though the effect is rather small, and statistically significant only for the latter. Contrary to the predictions of the outbidding model, support for both of these

\footnotetext{
${ }^{2}$ Garfinkel (2004) also studies the effects of terrorism on domestic politics, but focuses on the struggle for power within the entity that is subject to an external terrorist threat.
} 
factions remains essentially unchanged when the other faction engages in violence. Fatah's and Hamas' gains in support from successful attacks against Israelis do not come at the expense of each other's support. Rather, Hamas gains public support mostly at the expense of other Islamist groups like Palestinian Islamic Jihad and the disaffected (those who support no one), while Fatah gains mostly at the expense of supporters of other secular groups like the Popular and Democratic Fronts for the Liberation of Palestine (PFLP and DFLP, respectively). Notably, Israeli fatalities caused by PIJ are associated with a large and statistically significant decrease in support for it, as well as a decrease in support for Hamas, while the ranks of the disaffected increase. These results suggest that to the extent that violence causes shifts in support, these shifts occur largely within either the secular (Fatah, PFLP and DFLP) or Islamist (Hamas, PIJ) factions and not between the secular and Islamist groups.

\section{Data}

For the purposes of the current study we combine two separate data sets: one describes the political preferences of the Palestinian population while the other contains detailed information on all the Israeli and Palestinian fatalities during the second Palestinian uprising.

The information on Palestinians' political preferences comes from a set of surveys conducted by the Development Studies Programme (DSP) at Bir Zeit University. This institute has conducted regular public opinion polls on all aspects of Palestinian life since the year 2000. Every poll has around 1,200 observations, with approximately two thirds of them from the West Bank and Jerusalem and the rest from the Gaza Strip. General information on these polls, including summary results and demographic information are available from Jaeger et al. (2010). 
In this paper, we focus exclusively on the preferences of the Palestinian population across the different Palestinian political factions. The exact wording of the question of interest is "Which of the following political groups do you support?" The available answers include Fatah and Hamas, the two major Palestinian factions during the time period of interest. They also included other popular factions like the Palestinian Islamic Jihad as well as the Popular Front for the Liberation of Palestine (PFLP) and the Democratic Front for the Liberation of Palestine (DFLP), the two main leftist factions. In addition, respondents who stated that they were independent were asked whether their preferences leaned towards Fatah, to one of the Islamic factions, or to one of the leftist factions. We coded independents leaning towards one of the factions together with that faction's outright supporters. We also coded all the Islamic factions (except Hamas) together with PIJ. The question on political support appeared in 15 polls between February 2001 and May 2006, for a total of 17,406 observations. ${ }^{3}$

Figure 1 depicts the evolution of Palestinians political preferences over time. We summarize these movements on an annual basis in Table 1. Over the whole period of interest, support for Fatah is on average 29.1 percent while Hamas receives 23.0 percent of the population's support. The support for PIJ equals almost ten percent, very similar to the support enjoyed by other groups (comprised mostly by the leftist groups PFLP and DFLP). Notably, the proportion of respondents reporting that they do not support any group was 28.5 percent, nearly as large as the proportion supporting Fatah. This suggests that a large fraction of the Palestinian

\footnotetext{
${ }^{3}$ In particular, this question appeared in three surveys in each of the years 2001, 2003, 2004 and 2006 , in two surveys in 2002, and in one survey in 2005.
} 
population feels disaffection from the Palestinian political factions. We address this issue in our empirical analysis and characterize the attitudes of this group.

Focusing on the factions' average support over the entire time period of interest masks, however, interesting secular shifts in the political preferences of the Palestinian population that occurred over time. The support for Fatah began at around 23 percent in 2001 and peaked in September 2005 at 43.72 percent. After the death of Yasser Arafat, support for Fatah increased by more than 10 percentage points. Support for Hamas has also been variable, reaching its lowest point of about 15 percent in early 2003 and peaking at nearly 40 percent in March 2006. Support for PIJ and the other Islamic faction has been relatively steady except for in 2003 when it increased substantially, largely at the expense of support for Hamas. The degree of disaffection (support for no one) and other groups was relatively high in the first years of the Intifada, but has declined since 2003, seemingly mostly to the benefit of Fatah.

Information on Israeli and Palestinian fatalities during the second Intifada is taken from B'tselem, an Israeli human rights organization. B'tselem's data (thought to be accurate, reliable, and comprehensive) are widely used in studies focusing on the Israeli-Palestinian conflict (Becker and Rubinstein 2008, Jaeger and Paserman 2006, 2008, 2009, Gould and Klor 2010, and others). The data include information on the date, location, and circumstances of each fatality (excluding suicide bombers), which allows us to classify every Palestinian fatality according to 
the Palestinian district where the incident took place, and every Israeli fatality according to the district where the attack originated. ${ }^{4}$

We then cross-validated the B'tselem data with data downloaded between 2005 and 2006 from the web site of the International Institute for Counter-Terrorism (ICT) in Hertzliya, Israel (http://www.ict.org.il), ${ }^{5}$ from the Israeli Ministry of Foreign Affairs, and from published newspaper reports from the Jerusalem Post and other media outlets. These data were used to identify the group claiming responsibility for every Israeli fatality. Thanks to the use of multiple sources, we were able to identify the faction responsible for the attack for 99 percent of all Israeli fatalities. ${ }^{6}$

This paper's primary concern is not how Palestinian public opinion varies with the number of fatalities (an issue we have previously explored in Jaeger, et al. 2010), but rather whether public opinion varies with violence claimed by different factions. In Figure 2 we show the share

\footnotetext{
${ }^{4}$ In the isolated instances in which it was not possible to identify the district of origin of the attacker, we assumed that the district of origin was the Palestinian district nearest to the place of the attack.

5 The database with information on all fatalities during the Intifada is no longer publicly available on the ICT web site.

${ }^{6}$ Israeli fatalities unaccounted for are classified as claimed by "other" groups. There is a small number of cases in which more than one group claimed responsibility for an attack, or an attack was carried out jointly by more than one group. In these cases, we tried to use the best of our own judgment to assign a unique faction to each fatality. Excluding these cases from the analysis has no substantive effect on the results.
} 
of Israeli fatalities claimed by the different factions aggregated quarterly (there are too few fatalities for this graph to be meaningful at the weekly level). There is a fair amount of variability in which faction claims responsibility. Prior to the $2005 \mathrm{Hudna}$, or period with a cease-fire, most fatalities are claimed by either Fatah or Hamas, with Palestinian Islamic Jihad and other Islamic factions occasionally becoming the primary actors. After 2005, nearly all fatalities are claimed by PIJ and other groups. Thus, there is a large degree of variation to identify our model of outbidding.

\section{Empirical Framework}

We set up a discrete choice model to study the effects of Palestinian and Israeli violence on support for the different Palestinian factions. We start from a random utility model where we specify the individual's utility from each one of the five different possible choices: Fatah, Hamas, PIJ, Others and No One, labeled from 0 to 4 . Let $U_{j i d t}$ be the utility from faction $j$ for individual $i$ living in district $d$ at time $t$ :

$$
U_{j i d t}=\alpha_{j}^{\prime} \mathbf{P}_{d t}+\sum_{k=0}^{3} \beta_{j k}^{\prime} \mathbf{I}_{d t}^{k}+\mathbf{X}_{i d t} \Phi_{j}+\delta_{t j}+\mu_{d j}+\varepsilon_{j i d t}, \quad \text { for } j=0,1, \ldots, 4
$$

where $\mathbf{P}_{d t}$ is a vector of lags of Palestinian fatalities that occurred in district $d$ at time $t ; \quad \mathbf{I}_{d t}^{k}$ is a vector of lags of Israeli fatalities caused by faction $k$, originating from district $d$ at time $t$ (notice that $\mathbf{I}_{d t}^{4}=0$, since there are no fatalities claimed by "No One", faction number 4); $\mathbf{X}_{i d t}$ is a vector of individual, district, or time-specific characteristics; $\delta_{t j}$ is a faction-specific, time fixed effect; $\mu_{d j}$ is a faction-specific, district fixed effect; $\varepsilon_{j i t d}$ is an error term with a type-1 extreme value distribution; and $\left\{\alpha_{j},\left\{\beta_{j k}\right\}_{k=0}^{3}, \Phi_{j}\right\}_{j=1}^{4}$ are parameters to be estimated (we already impose 
here the normalization that $\alpha_{0},\left\{\beta_{0 k}\right\}_{k=0}^{3}$, and $\Phi_{0}$ are all equal to zero, which is necessary for identification). As is well known, this model gives rise to the multinomial logit choice probabilities. That is, the probability that individual $i$ chooses faction $j$ is equal to:

$$
P\left(Y_{i d t}=j \mid \mathbf{P}_{d t},\left\{\left\{_{d t}^{k}\right\}_{k=1}^{\xi}, \mathbf{X}_{i d t}\right)=\frac{\exp \left(\alpha_{j}^{\prime} \mathbf{P}_{d t}+\sum_{k=0}^{3} \beta_{j k}^{\prime} \mathbf{I}_{d t}^{k}+\mathbf{X}_{i d t} \Phi_{j}+\delta_{t j}+\mu_{d j}\right)}{1+\sum_{l} \exp \left(\alpha_{l}^{\prime} \mathbf{P}_{d t}+\sum_{k} \beta_{l k}^{\prime} \mathbf{I}_{d t}^{k}+\mathbf{X}_{i d t} \Phi_{l}+\delta_{t l}+\mu_{d l}\right)}\right.
$$

We will also estimate a simplified version of equation (2), where we look at the effect of overall Israeli fatalities on support for the different factions. This equation will tell us more generally how violence against Israeli targets affects public opinion. The choice probabilities then become:

$$
P\left(Y_{i d t}=j \mid \mathbf{P}_{d t},\left\{\mathbf{I}_{d t}^{k}\right\}_{k=1}^{3}, \mathbf{X}_{i d t}\right)=\frac{\exp \left[\alpha_{j}^{\prime} \mathbf{P}_{d t}+\beta_{j}^{\prime}\left(\sum_{k=0}^{3} \mathbf{I}_{d t}^{k}\right)+\mathbf{X}_{i d t} \Phi_{j}+\delta_{t j}+\mu_{d j}\right]}{1+\sum_{l} \exp \left[\alpha_{l}^{\prime} \mathbf{P}_{d t}+\beta_{l}^{\prime}\left(\sum_{k} \mathbf{I}_{d t}^{k}\right)+\mathbf{X}_{i d t} \Phi_{l}+\delta_{t l}+\mu_{d l}\right]} .
$$

It is worth remarking on a number of features of equation (2).

1) Flexible specification. The model assumes that the utility derived from a given faction depends not only on the number of (lagged) Israeli fatalities claimed by that faction, but also on the number of Israeli fatalities claimed by all other factions. This allows a completely flexible pattern of own and cross effects. That is, it is possible that fatalities claimed by one faction (say, Hamas) raise public support for that faction, while fatalities claimed by a different faction (say, PIJ) lower support for it. Also, fatalities claimed by one faction may raise public support for that faction, but this does not need to be at the expense of all the other factions: some factions may enjoy positive spillover effects from the violence claimed by some of its rivals. Finally, the 
flexible specification allows us to learn something about the pattern of competition between the different factions: for example, if Hamas gains public support as a result of a high number of Israeli fatalities claimed by it, does this come at the expense of Fatah, its main rival for the leadership of the Palestinian Authority, or at the expense of PIJ, a faction that is probably closer to Hamas in policy space?

2) Lag structure. The vectors $\mathbf{P}_{d t}$ and $\left\{\mathbf{I}_{d t}^{k}\right\}_{k=0}^{k}$ contain several lags of Palestinian and Israeli fatalities. Following our previous work (Jaeger et al., 2010), we allow fatalities in each one of the three four-week periods prior to the survey to have a different effect on the choice probabilities. The vector $\mathbf{P}_{d t}$ is defined as $\mathbf{P}_{d t}=\left(P_{d t-1}, P_{d t-2}, P_{d t-3}\right)^{\prime}$, where $P_{d t-s}$ is the number of Palestinian fatalities that occurred in district $d$ in the $s^{\text {th }}$ four-week period prior to the survey date. Similarly, $\mathbf{I}_{d t}^{k}=\left(I_{d t-1}^{k}, I_{d t-2}^{k}, I_{d t-3}^{k}\right)^{\prime}$, where $I_{d t-s}^{k}$ is the number of Israeli fatalities claimed by faction $k$ and originating in district $d$ in the $s^{\text {th }}$ four-week period prior to the survey date. Therefore, the choice probabilities become:

$$
P\left(Y_{i d t}=j \mid \mathbf{P}_{d t},\left\{\mathbf{I}_{d t}^{k}\right\}_{k=1}^{3}, \mathbf{X}_{i d t}\right)=\frac{\exp \left[V_{j i d t}\right]}{1+\sum_{l} \exp \left[V_{\text {lidt }}\right]},
$$

with

$$
V_{j i d t}=\alpha_{j 1} P_{d t-1}+\alpha_{j 2} P_{d t-2}+\alpha_{j 3} P_{d t-3}+\sum_{k=0}^{3}\left(\beta_{j k 1} I_{d t-1}^{k}+\beta_{j k 2} I_{d t-2}^{k}+\beta_{j k 3} I_{d t-3}^{k}\right)+\mathbf{X}_{i d t} \Phi_{j}+\delta_{t j}+\mu_{d j}
$$

Given this definition, the individual elements of $\alpha_{j}$ and $\beta_{j k}$ represent the effect of a onetime increase in violence occurring exactly in one of the three four-week periods before the survey on the support for faction $j$. Since the time pattern of the coefficients may be difficult to interpret, we also report results from simulations where we introduce a permanent increase in the 
number of fatalities claimed by each one of the factions, and study the effect of this change on the different choice probabilities.

3) Time and district fixed effects. The inclusion of time and district fixed effects is key for our analysis. There is substantial variability in the number of Israeli and Palestinian fatalities across Palestinian districts. If the Palestinian population is sorted across districts according to their political preferences and violence occurs mainly in radical districts, a simple cross-sectional analysis would yield a spurious correlation between radical attitudes and violence. The availability of longitudinal data allows us to exploit both the time series and the cross-sectional variability in our analysis. The inclusion of district fixed effects allows to hold constant timeinvariant district attributes, and to achieve identification only from the within-district variation in political attitudes and in the number of fatalities. Similarly, the inclusion of time fixed effects allows us to control for common factors that affect support for the different factions uniformly across all districts at a point in time (e.g., the death of Arafat, and the surge in support for Fatah that came with it).

Finally, we must recognize that our empirical strategy may yield a biased estimate of the causal effect of Palestinian violence on support for the different factions, if the factions respond endogenously to swings in public opinion by engaging in attacks against Israeli targets. If this were the case, our coefficients would be picking up the effect of public opinion on Israeli fatalities, rather than the effect of fatalities on public opinion. We are somewhat reassured that this is not the case, because we do not find any evidence that Israeli fatalities in the weeks that follow the survey are correlated with the share of support for the different factions (results available upon request). The reason for this is that probably attacks against Israeli targets require a substantial amount of planning, so that it is unlikely that the number of fatalities will respond 
very rapidly to changes in public opinion. While this evidence does not completely rule out the possibility of reverse causality, we believe that it is unlikely that it will affect the results substantively.

\section{Results}

We initially examine the effect of overall Israeli and Palestinian violence on support for the different Palestinian factions. As explained in the previous section, we estimate a multinomial logit model for faction supported. The results are presented in Table 2. To facilitate comparison across tables, we present the marginal effects of violence on the support for each faction, rather than the multinomial logit coefficients. In addition to the individual marginal effects for the number of Palestinian and Israeli fatalities at different lag lengths, we also report the sum of the three marginal effects. This number tells us the effect of a permanent one-unit increase in the number of fatalities.

The results from this analysis show that increases in Palestinian fatalities shift support away from all the political factions in the short run. The size of the decrease in political support for Palestinian factions, however, is not statistically or quantitatively significant. The greatest shift is away from Fatah, and it translates into a decrease in support of roughly one percentage point in the four weeks prior to a poll for every ten additional Palestinian fatalities. This shift away from political factions in the short run is not only small, but it also dissipates over time. As a consequence, Palestinian fatalities do not cause a permanent shift on the preferences of the Palestinian population, as can be seen from the fact that the sum of the marginal effects is always small and insignificant. 
Contrary to the changes suffered by all the political factions, we observe a significant increase in the number of disaffected Palestinians in the short run. The coefficient on "supporting no one" is, by construction, equal to the sum of the coefficients on support for all other alternatives but with opposite sign. This significant shift towards disaffection may also reflect radicalization as well as disaffection: Jaeger et al. (2010) show that preferences of disaffected Palestinians are more radical than the preferences of supporters for Fatah, PLFP and DFLP but less radical than the preferences of Hamas and PIJ supporters. It is also possible that fatalities induce Palestinians to avoid expressing support for political factions, even if they do not really shift their actual political allegiance. This possibility seems less likely however, since the effect of an increase in Palestinian fatalities does not dissipate over time. Therefore, the permanent effect of Palestinian fatalities on disaffection is also positive, of an important magnitude, and statistically significant.

Contrary to the effect of Palestinian fatalities, Israeli fatalities do not seem to have a patterned effect on the support for any faction or disaffection, either in the short or long run. This basic specification uses the number of Israeli fatalities originating from each specific district as the explanatory variable. Though not reported in the table, the results are essentially the same when we use the number of Israeli fatalities aggregated at the national level or at the macro-regional level (i.e., West Bank and Gaza) instead of local fatalities as the explanatory variable.

We now turn our attention to the main question of this paper, namely whether there is any support for the hypothesis that Palestinian factions can gain public support by engaging in violence against Israel. In Table 3 we present the marginal effects from the multinomial logit model described in equation (2), where we include separately the number of fatalities claimed by 
the different factions (Fatah, Hamas, PIJ, and all others) as explanatory variables, at different time lags. Several of the marginal effects are statistically significant, and one can soundly reject the null hypothesis that Israeli fatalities have no effect on faction support for three of the four factions, while the overall effect of Fatah-claimed fatalities is only marginally insignificant.

It is somewhat difficult, however, to identify a clear pattern for the individual coefficients. Focusing only on the short run, it appears that Palestinian fatalities lower support for Fatah and raise disaffection; Fatah-claimed fatalities have no effect on any factions; Hamasclaimed fatalities lower the number of disaffected; PIJ-claimed fatalities raise the number of disaffected, at the expense of both Hamas and PIJ; and fatalities claimed by others raise support for other factions and PIJ, at the expense of Hamas and the disaffected.

To get a better sense of the magnitude of the effects, we present in Table 4 the results of simulations where we evaluate how support for the different factions changes as a result of a permanent two-standard deviation increase in the number of Palestinian fatalities and the number of Israeli fatalities claimed by each faction. Specifically, in evaluating the effect of a permanent increase in violence by faction $k$, we take the following steps:

a) Calculate the standard deviation of fatalities claimed by faction $k$ for each of the three 4week intervals preceding the poll, separately;

b) Take the simple average of these three numbers;

c) Add twice the resulting average to the number of fatalities claimed by faction $k$ in each one of the three 4-week intervals.

d) Re-evaluate the choice probabilities using the estimated model parameters. 
Standard errors for the estimates are obtained by taking 5,000 draws from the estimated parameter vector, and calculating the standard deviation of the predicted change in choice probabilities.

The top row of Table 4 shows the benchmark choice probabilities for each one of the five factions. Then, each row shows the change in support for each faction (in percentage terms) as a result of a permanent increase in violence by Israel or by any of the factions. To highlight the own-faction effects (i.e., the change in support for the faction responsible for fatalities) we have boxed the numbers on the main diagonal of the matrix. Standard errors are in parenthesis.

Our results show that violence by the different factions does not have a large effect on Palestinian support for Fatah. While an increase in violence committed by Fatah increases Fatah's support and decreases support for Hamas and disaffection, these effects are negligible and not statistically significant. There is some evidence that Fatah-claimed fatalities lead to a small drop in support for other Palestinian factions.

The table provides, however, some evidence that the outbidding hypothesis applies to Hamas. A higher number of Israeli fatalities claimed by Hamas raises the relative support for this faction while lowering the share of disaffected Palestinians. Also, the second column shows that Hamas loses public support when PIJ and other factions claim a high number of Israeli fatalities.

We also observe that the outbidding hypothesis applies to the minor factions, grouped into the "others" category, which are able to significantly increase their popularity among the Palestinian public through the use of violence against Israelis. This increase in popularity comes at the expense of both Fatah and Hamas, and of the disaffected. 
Contrary to the predictions of the outbidding hypothesis, Israeli fatalities claimed by the PIJ cause an overall decrease in the support for PIJ, both in the short run and in the long run. Interestingly, PIJ violence leads to a large loss in public support for Hamas, the other radical faction, and leads to a large increase in disaffection among the Palestinian population. A possible explanation for this finding is that PIJ follows a spoiling strategy rather than a strategy of outbidding. In particular, a spoiling strategy refers to the attempt of extremist factions to commit attacks during times of particular cooperation between Israel and the leading Palestinian factions, in order to re-start a process of violence and distrust (Kydd and Walter 2002). While this strategy may be successful in derailing cooperation and trust between the Israeli government and the leading Palestinian factions, the data show that it may somewhat backfire for the PIJ with regards to enjoying the popular support of the Palestinian population. One possible explanation may be that the Palestinian public supports cooperation with Israel while it is occurring, and therefore shifts its preferences in favor of disaffection, a more moderate position than support for Hamas or PIJ, when PIJ commits attacks.

The magnitude of the effect is not very large, but also not negligible. For example, the 1.83 percentage point increase in support for Hamas as a result of an increase in Hamas-claimed fatalities is more than half as large as the increase in support for Hamas when going from the West Bank to the Gaza Strip (3.4 percentage points), about one fourth the size of the effect of going from a high school degree to a college degree (7.2 percentage points), and also about one fourth of the effect of going from the youngest (15-29 years old) to the oldest (ages 60 and up) age group (7.4 percentage points). Importantly, since fatalities claimed by Hamas also lower the share of disaffected Palestinians, this implies that the share of Hamas supporters among potential voters may actually increase by as much as 4.3 percentage points, 


\section{Conclusions}

In this paper we provide an empirical test of the hypothesis that Palestinian factions can effectively use violence to garner support from the Palestinian public, as measured through opinion polls. We find mixed support for this hypothesis. Permanent increases in violence by Fatah and Hamas appear to lead to increases in support for these factions, although not through reducing support for the other faction. Rather, violence claimed by Fatah appears to reduce the support of smaller, secular factions while violence claimed by Hamas appears to reduce disaffection (i.e. support for no one). Violence by the Palestinian Islamic Jihad and other Islamist factions appears to backfire in terms of garnering support for these factions, but also reduces support for Hamas and increases disaffection. Other groups (mostly the PFLP and the DFLP) also seem able to increase their support through violence. In contrast to these results, we find little evidence that violence by Israel shifts the balance of support in any particular direction.

All of the effects that we estimate are small relative to the average level of support for each faction in our data. This suggests that violence against Israelis plays a relatively minor role in determining support for Fatah and Hamas. Moreover, our results suggest support is not a zero-sum game between the two main factions. To the extent that violence increases support for Fatah, it comes at the expense of other secular factions like PFLP and DFLP. Similarly, increasing support for Hamas through violence comes at the expense of the PIJ and other Islamic factions. Thus, to the extent that violence shifts support, it seems to shift the balance of power within the secular factions and within the Islamic factions, but does relatively little to shift the balance between the secular (Fatah, PFLP, DFLP) and Islamist (Hamas, PIJ) factions. 
The current paper showed that Palestinian violence affects, to certain extent, the political preferences of the Palestinian population. Although effective, given the magnitude of the coefficients, we believe that a rational faction would not find it efficient to launch a terror attack with the exclusive goal of boosting its relative standing among the Palestinian public. Related research showed that terrorism is consistently used to reach other goals, like retaliation against Israeli targeted killings (Jaeger and Paserman 2009), creating political pressure in favor of territorial concessions (Pape 2005 and Gould and Klor 2010) and affecting the preferences of the Israeli population (Berrebi and Klor 2008 and 2006). ${ }^{7}$ Taking that into account, it seems that a strategy of outbidding cannot explain by itself the observed variation in factions' terror attacks against Israel, even if fluctuations in political support across factions are a consequence of factions' attacks.

\section{References}

Becker G. S. \& Rubinstein Y. (2010). Fear and the response to terrorism: an economic analysis. Unpublished manuscript, Brown University.

Berman, E., \& Laitin, D. D. (2008). Religion, Terrorism and Public Goods: Testing the Club Model. Journal of Public Economics, 92(10-11), 1942-1967.

Bernholz, P. (2004). Supreme Values as the Basis for Terror. European Journal of Political Economy, 20, 317-333.

Berrebi, C., \& Klor, E. F. (2006). On Terrorism and Electoral Outcomes: Theory and Evidence from the Israeli-Palestinian Conflict. Journal of Conflict Resolution, 50(6), 899-925.

Berrebi, C., \& Klor, E. F. (2008). Are Voters Sensitive to Terrorism? Direct Evidence from the Israeli Electorate. American Political Science Review, 102(3), 279-301.

\footnotetext{
${ }^{7}$ An alternative approach claims that terrorism is a consequence of individuals holding "supreme values" type of preferences (Bernholz, 2004).
} 
Blomberg, S.B., Hess, G.D. \& Weerapana, A. (2004) Economic Conditions and Terrorism. European Journal of Political Economy, 20(2), 463-478.

Bloom, M. (2004). Palestinian suicide bombing: Public support, market share and outbidding. Political Science Quarterly, 119(1), 61-88.

Bloom, M. (2005). Dying to kill: The allure of suicide terror. New York: Columbia University Press.

Bueno de Mesquita, E., \& Dickson, E. S. (2007). The Propaganda of the Deed: Terrorism, Counterterrorism, and Mobilization. American Journal of Political Science, 51(2), 364381.

de Figueiredo, R.J.P., Jr \& Weingast, B.R. (2001). Vicious cycles: Endogenous political extremism and political violence. Unpublished manuscript, Stanford University.

Garfinkel, M. R. (2004). Global threats and the domestic struggle for power. European Journal of Political Economy, 20(2), 495-508.

Gould E. D., \& Klor, E. F. (2010). Does Terrorism Work? The Quarterly Journal of Economics, forthcoming.

Jaeger, D. A., \& Paserman, M. D. (2006). Israel, the Palestinians Factions, and the Cycle of Violence. American Economic Review, 96(2), 45-49.

Jaeger, D. A., \& Paserman, M. D. (2008). The Cycle of Violence? An Empirical Analysis of Fatalities in the Palestinian-Israeli Conflict. American Economic Review, 98(4), 15911604.

Jaeger, D. A., \& Paserman, M. D. (2009). The Shape of Things to Come? Assessing the Effectiveness of Suicide Attacks and Targeted Killings. Quarterly Journal of Political Science, 4(4), 315-342.

Jaeger, D. A., Klor, E. F., Miaari, S. H., \& Paserman, M. D. (2010). The Struggle for Palestinian Hearts Minds: Violence and Public Opinion in the Second Intifada. Unpublished manuscript, Hebrew University of Jerusalem.

Kydd, A., \& Walter, B. F. (2002). Sabotaging the Peace: The Politics of Extremist Violence. International Organization, 56(2), 263-296.

Kydd, A., \& Walter, B. F. (2006). The strategies of terrorism. International Security, 31(1), 4980.

Lapan, H. E. and Sandler, T. (1993). Terrorism and Signaling. European Journal of Political Economy, 9, 383-398. 
Pape, R. A. (2005). Dying to win: The strategic logic of suicide terrorism. New York: Random House. 


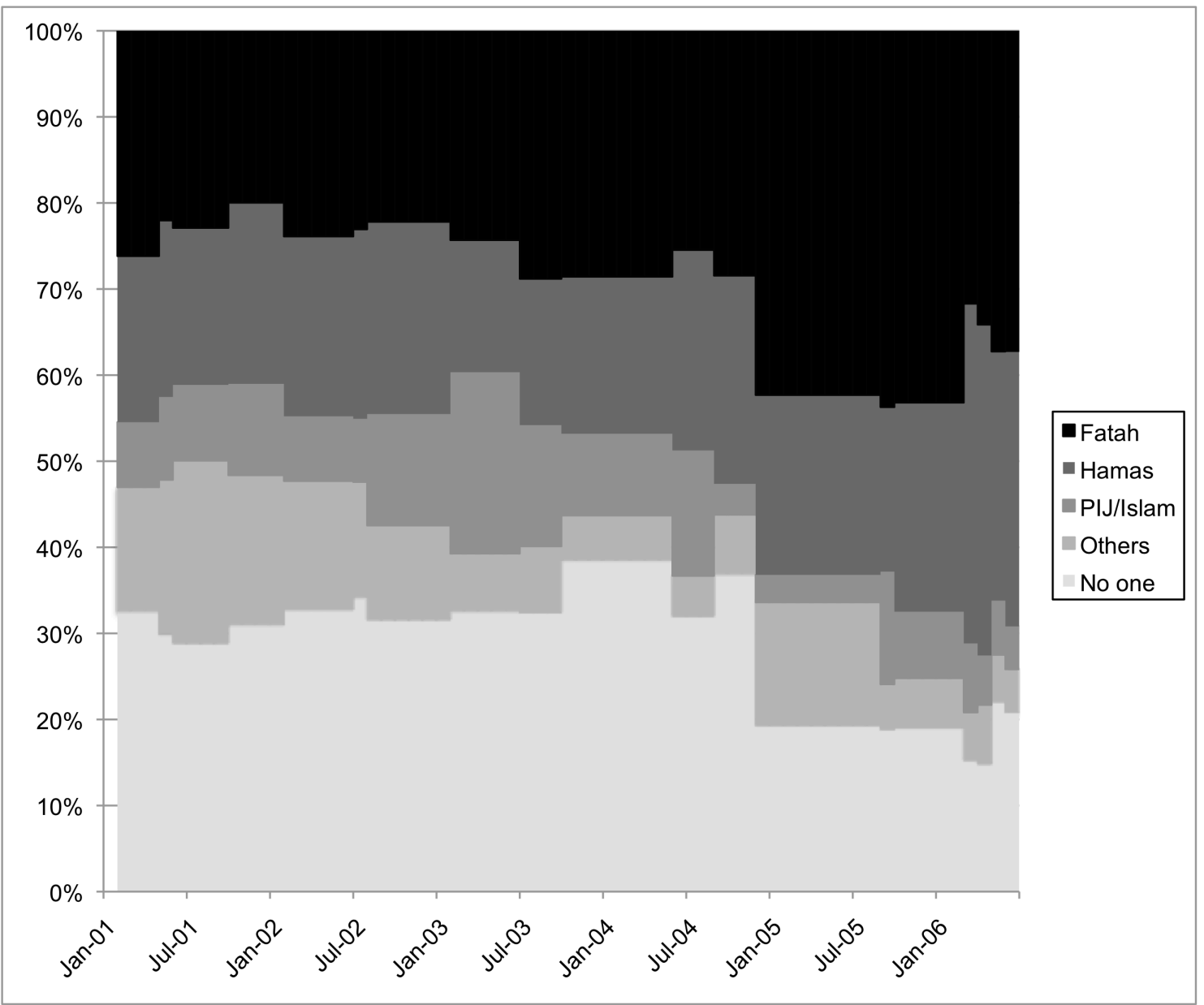

Figure 1: Palestinian Support for Different Factions, 2001-2006 


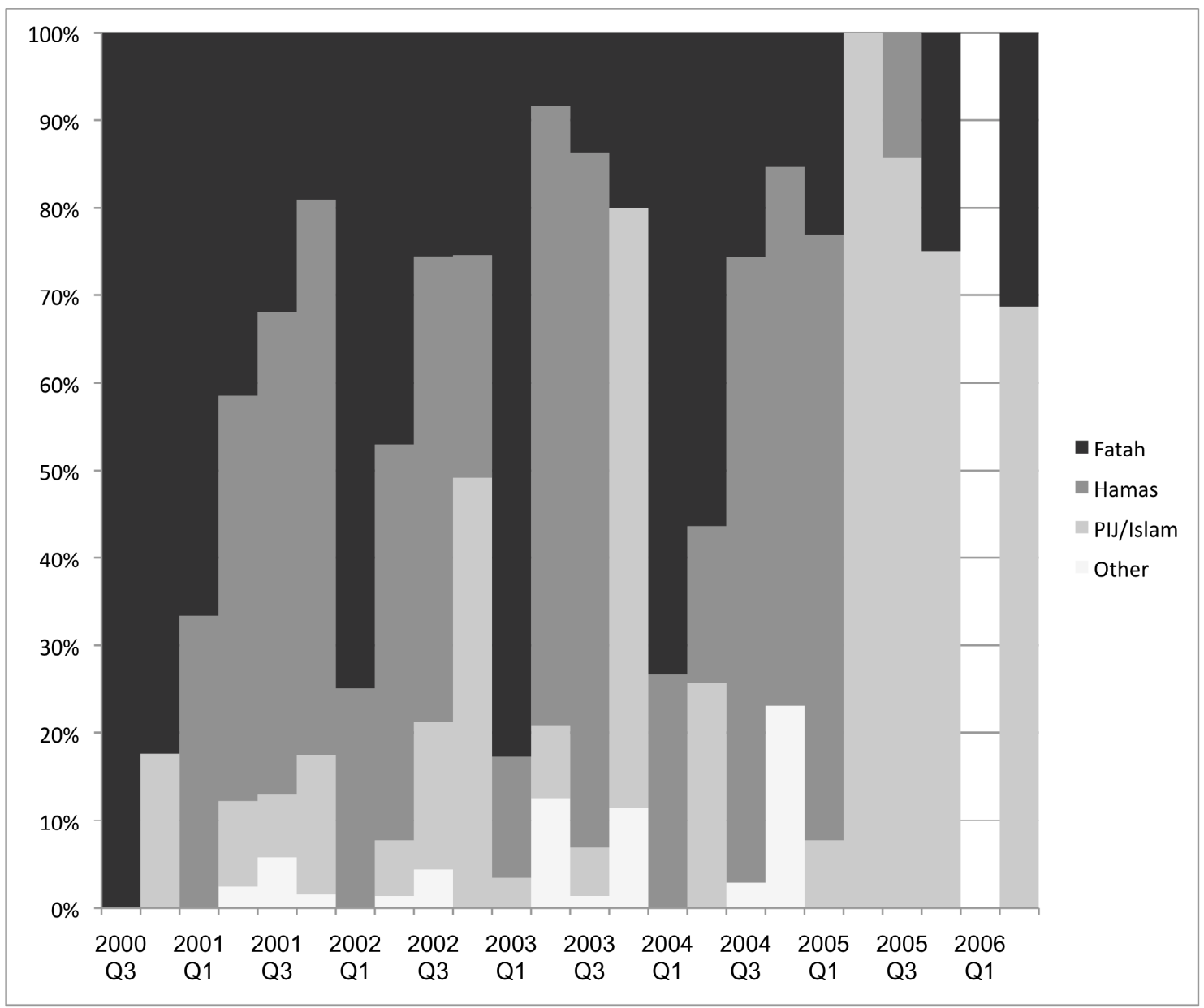

Figure 2: Palestinian Factions Claiming Responsibilities for Israeli Fatalities, 2001-2006 (quarterly) 
Table 1

Suport for Different Palestinian Factions Over Time

\begin{tabular}{|c|c|c|c|c|c|c|c|}
\hline \multirow[b]{2}{*}{ Factions } & \multicolumn{6}{|c|}{ Year } & \multirow[b]{2}{*}{$\begin{array}{l}\text { Entire } \\
\text { Period } \\
\end{array}$} \\
\hline & 2001 & 2002 & 2003 & 2004 & 2005 & 2006 & \\
\hline Fatah & $\begin{array}{l}22.91 \\
(815)\end{array}$ & $\begin{array}{l}23.22 \\
(552)\end{array}$ & $\begin{array}{l}27.15 \\
(999)\end{array}$ & $\begin{array}{c}32.07 \\
(1,151)\end{array}$ & $\begin{array}{l}43.36 \\
(519)\end{array}$ & $\begin{array}{c}34.40 \\
(1,034)\end{array}$ & $\begin{array}{c}29.13 \\
(5,070)\end{array}$ \\
\hline Hamas & $\begin{array}{l}19.79 \\
(704)\end{array}$ & $\begin{array}{l}21.54 \\
(512)\end{array}$ & $\begin{array}{l}16.82 \\
(619)\end{array}$ & $\begin{array}{l}22.79 \\
(818)\end{array}$ & $\begin{array}{l}22.64 \\
(271)\end{array}$ & $\begin{array}{c}35.93 \\
(1,080)\end{array}$ & $\begin{array}{c}23.00 \\
(4,004)\end{array}$ \\
\hline Palestinian Islamic Jihad and other Islamic Factions & $\begin{array}{r}9.08 \\
(323)\end{array}$ & $\begin{array}{r}9.09 \\
(216)\end{array}$ & $\begin{array}{l}15.05 \\
(554)\end{array}$ & $\begin{array}{c}7.11 \\
(255)\end{array}$ & $\begin{array}{r}9.44 \\
(113)\end{array}$ & $\begin{array}{r}6.49 \\
(195)\end{array}$ & $\begin{array}{c}9.51 \\
(1,656)\end{array}$ \\
\hline Others & $\begin{array}{l}17.29 \\
(615)\end{array}$ & $\begin{array}{l}13.46 \\
(320)\end{array}$ & $\begin{array}{r}6.55 \\
(241)\end{array}$ & $\begin{array}{r}8.64 \\
(310)\end{array}$ & $\begin{array}{l}5.60 \\
(67)\end{array}$ & $\begin{array}{r}5.66 \\
(170)\end{array}$ & $\begin{array}{c}9.90 \\
(1,723)\end{array}$ \\
\hline No One & $\begin{array}{c}30.92 \\
(1,100)\end{array}$ & $\begin{array}{l}32.69 \\
(777)\end{array}$ & $\begin{array}{c}34.43 \\
(1,267)\end{array}$ & $\begin{array}{c}29.40 \\
(1,055)\end{array}$ & $\begin{array}{l}18.96 \\
(227)\end{array}$ & $\begin{array}{l}17.53 \\
(527)\end{array}$ & $\begin{array}{c}28.46 \\
(4,953)\end{array}$ \\
\hline Total & $\begin{array}{l}100.00 \\
(3,557)\end{array}$ & $\begin{array}{l}100.00 \\
(2,377)\end{array}$ & $\begin{array}{l}100.00 \\
(3,680)\end{array}$ & $\begin{array}{l}100.00 \\
(3,589)\end{array}$ & $\begin{array}{l}100.00 \\
(1,197)\end{array}$ & $\begin{array}{l}100.00 \\
(3,006)\end{array}$ & $\begin{array}{c}100.00 \\
(17,406)\end{array}$ \\
\hline
\end{tabular}

Notes: Percentage support for each faction by year. Number in parentheses is the total number of observations in each cell. Source: Authors' calculations using poll data from DSP. 
Table 2

The Effect of Violence on Support for Different Factions

\begin{tabular}{|c|c|c|c|c|c|}
\hline \multirow[b]{2}{*}{ Variable } & \multicolumn{5}{|c|}{ Multinomial logit: Marginal Effects on support for } \\
\hline & Fatah & Hamas & PIJ/Islam. & Others & No One \\
\hline \multicolumn{6}{|l|}{ Palestinian fatalities prior to poll (100s): } \\
\hline-1 to 4 weeks & $\begin{array}{l}-0.109 \\
{[0.076]}\end{array}$ & $\begin{array}{l}-0.030 \\
{[0.061]}\end{array}$ & $\begin{array}{l}-0.066 \\
{[0.065]}\end{array}$ & $\begin{array}{l}-0.051 \\
{[0.054]}\end{array}$ & $\begin{array}{l}0.256 * * \\
{[0.116]}\end{array}$ \\
\hline-5 to 8 weeks & $\begin{array}{l}-0.044 \\
{[0.093]}\end{array}$ & $\begin{array}{l}-0.118 \\
{[0.094]}\end{array}$ & $\begin{array}{c}0.031 \\
{[0.062]}\end{array}$ & $\begin{array}{l}-0.008 \\
{[0.094]}\end{array}$ & $\begin{array}{c}0.139 \\
{[0.120]}\end{array}$ \\
\hline - 9 to 12 weeks & $\begin{array}{c}0.065 \\
{[0.041]}\end{array}$ & $\begin{array}{l}0.100 * * \\
{[0.051]}\end{array}$ & $\begin{array}{l}-0.054 \\
{[0.044]}\end{array}$ & $\begin{array}{l}-0.019 \\
{[0.042]}\end{array}$ & $\begin{array}{l}-0.091 \\
{[0.078]}\end{array}$ \\
\hline $\begin{array}{l}\text { Sum of the marginal effects (effect of permanent } \\
\text { increase in Palestinian fatalities) }\end{array}$ & $\begin{array}{l}-0.088 \\
{[0.120]}\end{array}$ & $\begin{array}{l}-0.049 \\
{[0.116]}\end{array}$ & $\begin{array}{l}-0.089 \\
{[0.100]}\end{array}$ & $\begin{array}{l}-0.078 \\
{[0.103]}\end{array}$ & $\begin{array}{l}0.304 * \\
{[0.175]}\end{array}$ \\
\hline \multicolumn{6}{|l|}{ Israeli fatalities prior to poll (100s): } \\
\hline - 1 to 4 weeks & $\begin{array}{l}-0.123 \\
{[0.119]}\end{array}$ & $\begin{array}{c}0.005 \\
{[0.129]}\end{array}$ & $\begin{array}{l}-0.064 \\
{[0.178]}\end{array}$ & $\begin{array}{c}0.117 \\
{[0.105]}\end{array}$ & $\begin{array}{c}0.065 \\
{[0.179]}\end{array}$ \\
\hline - 5 to 8 weeks & $\begin{array}{l}0.231 * \\
{[0.125]}\end{array}$ & $\begin{array}{l}-0.082 \\
{[0.098]}\end{array}$ & $\begin{array}{l}-0.099 * \\
{[0.056]}\end{array}$ & $\begin{array}{c}0.044 \\
{[0.094]}\end{array}$ & $\begin{array}{l}-0.095 \\
{[0.166]}\end{array}$ \\
\hline - 9 to 12 weeks & $\begin{array}{l}-0.074 \\
{[0.143]}\end{array}$ & $\begin{array}{l}0.180 \\
{[0.150]}\end{array}$ & $\begin{array}{c}0.089 \\
{[0.077]}\end{array}$ & $\begin{array}{l}-0.007 \\
{[0.082]}\end{array}$ & $\begin{array}{l}-0.188 \\
{[0.151]}\end{array}$ \\
\hline $\begin{array}{l}\text { Sum of the marginal effects (effect of permanent } \\
\text { increase in Israeli fatalities) }\end{array}$ & $\begin{array}{c}0.034 \\
{[0.220]}\end{array}$ & $\begin{array}{c}0.103 \\
{[0.205]}\end{array}$ & $\begin{array}{l}-0.073 \\
{[0.167]}\end{array}$ & $\begin{array}{c}0.153 \\
{[0.159]}\end{array}$ & $\begin{array}{l}-0.218 \\
{[0.290]}\end{array}$ \\
\hline$N$ & & & 17,406 & & \\
\hline
\end{tabular}

Source: Authors' calculations using fatality data from B'Tselem, poll data from DSP, labor market data from the Palestinian Labor Force Survey and border closures data from the Palestinian Ministry of Labor.

Note: Entries in table are marginal effects. All regressions include controls for residence type, gender, age, marital status, refugee status, education dummies, local unemployment rate, the local wage rate, the average number of closure days in the 30 days preceding the poll, and two period dummies. The models include 15 district fixed effects. Robust standard errors, adjusted for clustering at the poll-district level, in brackets; * indicates statistically significant at $10 \%$ level, ** indicates statistically significant at $5 \%$ level; *** indicates statistically significant at $1 \%$ level. 
Table 3

The Effect of Israeli Fatalities Claimed by Different Factions on Support for Different Factions

\begin{tabular}{|c|c|c|c|c|c|}
\hline \multirow[b]{2}{*}{ Varible } & \multicolumn{5}{|c|}{ Multinomial Logit: Marginal Effects for } \\
\hline & Fatah & Hamas & PIJ/ Islamic & Others & No one \\
\hline $\begin{array}{l}\text { Palestinian fatalities prior to poll (100s): } \\
-1 \text { to } 4 \text { weeks }\end{array}$ & $\begin{array}{l}-0.147 * \\
{[0.081]}\end{array}$ & $\begin{array}{c}0.062 \\
{[0.072]}\end{array}$ & $\begin{array}{r}-0.030 \\
{[0.062]}\end{array}$ & $\begin{array}{c}-0.063 \\
{[0.052]}\end{array}$ & $\begin{array}{l}0.178 * * \\
{[0.091]}\end{array}$ \\
\hline-5 to 8 weeks & $\begin{array}{l}-0.021 \\
{[0.098]}\end{array}$ & $\begin{array}{l}-0.154 \\
{[0.098]}\end{array}$ & $\begin{array}{r}0.025 \\
{[0.059]}\end{array}$ & $\begin{array}{c}0.035 \\
{[0.089]}\end{array}$ & $\begin{array}{l}0.115 \\
{[0.116]}\end{array}$ \\
\hline - 9 to 12 weeks & $\begin{array}{c}0.068 \\
{[0.045]}\end{array}$ & $\begin{array}{l}0.100 * \\
{[0.057]}\end{array}$ & $\begin{array}{c}-0.048 \\
{[0.045]}\end{array}$ & $\begin{array}{c}-0.026 \\
{[0.041]}\end{array}$ & $\begin{array}{l}-0.094 \\
{[0.075]}\end{array}$ \\
\hline $\begin{array}{l}\chi^{2} \text { test that Palestinian fatalities have no effect on faction } \\
\text { support ( } p \text {-value) }\end{array}$ & & & $\begin{array}{c}21.93 \\
(0.038)\end{array}$ & & \\
\hline $\begin{array}{l}\text { Israeli fatalities claimed by Fatah prior to poll, local (100s) } \\
\quad-1 \text { to } 4 \text { weeks }\end{array}$ & $\begin{array}{c}0.026 \\
{[0.508]}\end{array}$ & $\begin{array}{l}-0.071 \\
{[0.475]}\end{array}$ & $\begin{array}{r}0.353 \\
{[0.405]}\end{array}$ & $\begin{array}{c}-0.012 \\
{[0.304]}\end{array}$ & $\begin{array}{l}-0.296 \\
{[0.519]}\end{array}$ \\
\hline-5 to 8 weeks & $\begin{array}{c}0.134 \\
{[0.226]}\end{array}$ & $\begin{array}{l}0.647 * * * \\
{[0.253]}\end{array}$ & $\begin{array}{r}-0.107 \\
{[0.132]}\end{array}$ & $\begin{array}{l}-0.879 * * * \\
{[0.366]}\end{array}$ & $\begin{array}{l}0.205 \\
{[0.178]}\end{array}$ \\
\hline - 9 to 12 weeks & $\begin{array}{c}0.351 \\
{[0.242]}\end{array}$ & $\begin{array}{l}-0.471 * * \\
{[0.235]}\end{array}$ & $\begin{array}{c}-0.093 \\
{[0.156]}\end{array}$ & $\begin{array}{c}-0.056 \\
{[0.235]}\end{array}$ & $\begin{array}{l}0.267 \\
{[0.293]}\end{array}$ \\
\hline $\begin{array}{l}\chi^{2} \text { test that Israeli fatalities claimed by Fatah have no effect on } \\
\text { faction support ( } p \text {-value) }\end{array}$ & & & $\begin{array}{c}18.19 \\
(0.110)\end{array}$ & & \\
\hline $\begin{array}{l}\text { Israeli fatalities claimed by Hamas prior to poll (100s) } \\
-1 \text { to } 4 \text { weeks }\end{array}$ & $\begin{array}{l}-0.198 \\
{[0.121]}\end{array}$ & $\begin{array}{c}0.204 \\
{[0.130]}\end{array}$ & $\begin{array}{r}0.192 \\
{[0.207]}\end{array}$ & $\begin{array}{c}0.153 \\
{[0.170]}\end{array}$ & $\begin{array}{l}-0.352 * * \\
{[0.160]}\end{array}$ \\
\hline-5 to 8 weeks & $\begin{array}{l}0.467 * * \\
{[0.229]}\end{array}$ & $\begin{array}{l}-0.194 * * \\
{[0.093]}\end{array}$ & $\begin{array}{l}-0.147 * * \\
{[0.067]}\end{array}$ & $\begin{array}{l}0.197 * * \\
{[0.090]}\end{array}$ & $\begin{array}{l}-0.323 \\
{[0.308]}\end{array}$ \\
\hline - 9 to 12 weeks & $\begin{array}{l}-0.262 \\
{[0.252]}\end{array}$ & $\begin{array}{l}0.527^{* *} \\
{[0.257]}\end{array}$ & $\begin{array}{r}0.035 \\
{[0.127]}\end{array}$ & $\begin{array}{c}-0.007 \\
{[0.107]}\end{array}$ & $\begin{array}{l}-0.293 \\
{[0.214]}\end{array}$ \\
\hline $\begin{array}{l}\chi^{2} \text { test that Israeli fatalities claimed by Hamas have no effect } \\
\text { on faction support ( } p \text {-value) }\end{array}$ & & & $\begin{array}{c}53.52 \\
(0.000)\end{array}$ & & \\
\hline $\begin{array}{l}\text { Israeli fatalities claimed by PIJ prior to poll (100s) } \\
\quad-1 \text { to } 4 \text { weeks }\end{array}$ & $\begin{array}{c}0.166 \\
{[0.119]}\end{array}$ & $\begin{array}{l}-0.319 * * * \\
{[0.129]}\end{array}$ & $\begin{array}{l}-0.566 * * * \\
{[0.241]}\end{array}$ & $\begin{array}{c}0.077 \\
{[0.081]}\end{array}$ & $\begin{array}{l}0.642 * * * \\
{[0.229]}\end{array}$ \\
\hline-5 to 8 weeks & $\begin{array}{l}-0.030 \\
{[0.417]}\end{array}$ & $\begin{array}{l}-0.885 \\
{[0.727]}\end{array}$ & $\begin{array}{l}-0.518 * \\
{[0.271]}\end{array}$ & $\begin{array}{c}0.095 \\
{[0.147]}\end{array}$ & $\begin{array}{l}1.337 * * * \\
{[0.297]}\end{array}$ \\
\hline - 9 to 12 weeks & $\begin{array}{l}-0.293 \\
{[0.321]}\end{array}$ & $\begin{array}{c}0.010 \\
{[0.172]}\end{array}$ & $\begin{array}{r}0.003 \\
{[0.112]}\end{array}$ & $\begin{array}{c}0.104 \\
{[0.126]}\end{array}$ & $\begin{array}{l}0.176 \\
{[0.427]}\end{array}$ \\
\hline $\begin{array}{l}\chi^{2} \text { test that Israeli fatalities claimed by PIJ have no effect on } \\
\text { faction support ( } \mathrm{p} \text {-value) }\end{array}$ & & & $\begin{array}{c}60.09 \\
(0.000)\end{array}$ & & \\
\hline $\begin{array}{l}\text { Israeli fatalities claimed by others prior to poll (100s) } \\
-1 \text { to } 4 \text { weeks }\end{array}$ & $\begin{array}{l}-2.154 \\
{[2.303]}\end{array}$ & $\begin{array}{l}-9.680 * * * \\
{[2.727]}\end{array}$ & $\begin{array}{l}2.468 * \\
{[1.472]}\end{array}$ & $\begin{array}{l}13.012 * * * \\
{[4.199]}\end{array}$ & $\begin{array}{l}-3.646 * * \\
{[1.724]}\end{array}$ \\
\hline-5 to 8 weeks & $\begin{array}{l}-1.534 * * \\
{[0.737]}\end{array}$ & $\begin{array}{l}1.650 * * * \\
{[0.521]}\end{array}$ & $\begin{array}{l}1.007 * * * \\
{[0.418]}\end{array}$ & $\begin{array}{l}-1.285 * * * \\
{[0.522]}\end{array}$ & $\begin{array}{l}0.162 \\
{[0.948]}\end{array}$ \\
\hline - 9 to 12 weeks & $\begin{array}{c}1.257 \\
{[2.340]}\end{array}$ & $\begin{array}{c}1.685 \\
{[1.943]}\end{array}$ & $\begin{array}{r}-0.196 \\
{[2.088]}\end{array}$ & $\begin{array}{l}3.973 * * * \\
{[1.641]}\end{array}$ & $\begin{array}{l}-6.719 * * * \\
{[2.191]}\end{array}$ \\
\hline $\begin{array}{l}\chi^{2} \text { test that Israeli fatalities claimed by Others have no effect } \\
\text { on faction support ( } p \text {-value) }\end{array}$ & & & $\begin{array}{c}63.68 \\
(0.000)\end{array}$ & & \\
\hline $\begin{array}{l}N \\
\text { Number of poll } \times \text { district clusters }\end{array}$ & & & $\begin{array}{c}17,406 \\
237\end{array}$ & & \\
\hline
\end{tabular}

Source: Authors' calculations using fatality data from B'Tselem, poll data from DSP, labor market data from the Palestinian Labor Force Survey and border closures data from the Palestinian Ministry of Labor.

Note: Entries in the table represent marginal effects. All regressions include controls for area, residence type, gender, age, marital status, refugee status, religion, education dummies, local unemployment rate, the local wage rate, the average number of closure days in the 30 days preceding the poll, and period controls. Robust standard errors, adjusted for clustering at the poll-district level, in brackets; * indicates statistically significant at $10 \%$ level, $* *$ indicates statistically significant at $5 \%$ level; *** indicates statistically significant at $1 \%$ level. 
Table 4

Permanent Effect of Factions' Increase on Violence on their Support

\begin{tabular}{|c|c|c|c|c|c|}
\hline & \multicolumn{5}{|c|}{ Support for: } \\
\hline & Fatah & Hamas & PIJ & Others & No One \\
\hline Benchmark & 29.13 & 23.00 & 9.51 & 9.90 & 28.46 \\
\hline \multicolumn{6}{|c|}{ Percentage change in supports as a result of a permanent increase in violence by: } \\
\hline \multirow[t]{2}{*}{ Israel } & -0.96 & 0.09 & -0.59 & -0.61 & 2.07 \\
\hline & $(1.29)$ & $(1.25)$ & $(1.02)$ & $(1.08)$ & $(1.65)$ \\
\hline \multirow[t]{2}{*}{ Fatah } & 1.13 & 0.18 & 0.37 & $-2.09 *$ & 0.41 \\
\hline & $(1.43)$ & $(1.37)$ & (1.19) & $(1.15)$ & $(1.35)$ \\
\hline \multirow[t]{2}{*}{ Hamas } & -0.20 & $1.83 *$ & 0.28 & 1.42 & $-3.33 * *$ \\
\hline & $(1.29)$ & $(1.10)$ & $(1.09)$ & $(1.08)$ & $(1.37)$ \\
\hline \multirow[t]{2}{*}{ PIJ } & -0.55 & $-2.87 *$ & $-2.57 * * *$ & 0.64 & $5.35 * * *$ \\
\hline & (1.64) & (1.57) & $(0.81)$ & $(0.79)$ & (1.59) \\
\hline \multirow[t]{2}{*}{ Others } & -1.67 & $-2.52 * *$ & 0.94 & $7.27 * * *$ & $-4.02 * * *$ \\
\hline & $(1.36)$ & $(1.20)$ & $(0.97)$ & $(2.57)$ & (1.17) \\
\hline
\end{tabular}

Notes: Entries in the table show the percentage change in choice probabilities as a result of a permanent, two-standard deviation increase in the number of fatalities claimed by each faction. The choice probabilities are calculated based on the parameter estimates from the model in Table 3. See text for a full description of the procedure for calculating choice probabilities and standard errors. 